\title{
Autobiografia "não-autorizada": por uma experiência limiar no documentário na primeira pessoa
}

\author{
Roberta Veiga*
}

Resumo: Com a ampliação das produções audiovisuais caseiras, as formas de exposição do eu se intensificam e ganham novos contornos. Propomos compreender como o documentário na primeira pessoa interpela esse cenário reafirmando a espetacularização ou se abrindo para uma experiência limiar. Pensando a noção de "autobiografia não-autorizada", a ideia é compreender, a partir de quatro filmes brasileiros, o efeito de eu em jogo, as tensões na figuração da memória, e os modos como o filme diz de seu processo.

Palavras-chave: "autobiografia não autorizada"; documentário na primeira pessoa; experiência limiar; memória.

Resumen: Con la expansión de las producciones audiovisuales caseras, las formas de exposición del yo se intensifican y adquieren nuevos contornos. Proponemos comprender cómo el documental en primera persona desafía ese escenario reafirmando la espectacularización o abriéndose hacia una experiencia umbral. Pensando en la noción de "autobiografía no autorizada", la idea es entender, a partir de cuatro películas brasileñas, el efecto del yo en juego, las tensiones en la figuración de la memoria y los modos en los que la película dice de su proceso.

Palabras clave: "autobiografía no autorizada"; documental en primera persona; experiencia umbral; memoria.

Abstract: With the multiplication of homemade audiovisual productions, the exposure of the self was intensified and gained new outlines. I investigate whether Brazilian first-person documentaries endorse the spectacularization of the self or rather promote a threshold experience. As the notion of "unauthorized autobiography" is deployed in the analysis of four Brazilian films, I examine the effect of the self in filmmaking, the different ways of depicting memory, and how the films deal with its own process.

Keywords: "unauthorized autobiography"; first-person documentary; threshold experience; memory.

Résumé: Avec l'expansion des productions dites “maison” dans l'audiovisuel, les formes d'exposition du moi s'intensifient et acquièrent de nouveaux contours. Nous nous proposons de comprendre comment le documentaire à la première personne aborde ce scénario, soit en en réaffirmant l'aspect spectaculaire, soit, au contraire, en s'ouvrant à une expérience de seuil. Ayant dans l'esprit la notion d' " autobiographie non autorisée », l'idée est de comprendre, à partir de quatre films brésiliens, l'effet du moi

* Universidade Federal de Minas Gerais, Departamento de Comunicação Social, Programa de Pós-Gradução em Comunicação. 31270-901, Belo Horizonte, Brasil. E-mail: roveigadevolta@gmail.com

Submissão do artigo: 31 de dezembro de 2015. Notificação de aceitação: 14 de fevereiro de 2016.

Doc On-line, n. 19, março de 2016, www.doc.ubi.pt, pp. 42-59. 
qui est en jeu, les tensions dans la figuration de la mémoire, et les façons dont le film lui-même parle de son processus.

Mots-clés: « autobiographie non autorisée », documentaire à la première personne, expérience de seuil, mémoire

\section{Da cena do eu à implicação teórico-conceitual}

Com a ampliação das produções audiovisuais caseiras e a facilidade do compartilhamento pelas redes sociais, possibilitadas principalmente pelos dispositivos dos aparelhos celulares, as formas de inscrição do eu "na" e "pela" imagem se intensificaram enormemente. De um lado podemos pensar que o ato de virar a câmera para si, em toda e qualquer situação, reforça o fenômeno da espetacularização tal qual descrito por Guy Debord: "tudo que era diretamente vivido se esvai na fumaça da representação" (Debord, 1972: 13). Trata-se de um cenário no qual, de forma muito automática e acompanhando um padrão de representação, o sujeito reproduz um ato simbólico já nomeado e referendado pela grande mídia e pelas redes sociais, que garantirá sua identificação imediata no modus operandi de um sistema, assim como o é a marca no capitalismo tardio. Ao produzir uma selfie ou um vídeo-confessional, o sujeito se alinha a uma função da imagem na qual a própria (enquanto imagem técnica) não existe como tal, mas atende a lógica exposição-consumo típica das mercadorias onde aparecer vale mais do que ser. Segundo Paula Sibilia, na esteira de Debord, a espetacularização de si seria o adestramento da vida pessoal pelas formas de representação midiáticas: "essa subjetividade deverá se estilizar como um personagem da mídia audiovisual: deverá cuidar e cultivar sua imagem mediante uma bateria de habilidades e recursos" (Sibilia, 2008: $50)$.

Ao mesmo tempo, nas redes e em outras esferas audiovisuais, surgem experimentações que parecem não compactuar com o uso ultra-simbólico do aparato, no qual a câmera não mais espera pelo acontecimento, mas é apenas um meio de se reproduzir um comportamento visual programado para ser um vídeo-foto-selfie, que já possui, ele mesmo, um ser, uma identidade. Escapar dessa dimensão ultra-simbólica significa colocar o eu a distância e tornar o autorretrato uma experiência através da qual o sujeito se desconstrói e se (re)elabora. Nesse caso, a câmera é um dispositivo mediador, pois criador de uma possibilidade estética que refunda a tensão constituinte entre ser e aparecer e inverte, ou subverte, esse regime de visibilidade. Em tal experiência, o aparato produz uma relação de liminaridade com o sujeito que está em vias de, através dele, se transformar em imagem, colocando-o no limite constituinte da própria subjetividade que está entre o si e a produção de si. Jean Marie 
Gagnebin lembra que Walter Benjamin se preocupava com o fato das experiências liminares estarem sendo substituídas por um achatamento da superfície sensorial e psíquica, um apagamento das diferenças, e um nivelamento universal - que seria o próprio espetáculo de Debord - orientado pela novidade mercadológica e pelo lucro.

Se o tempo na modernidade - em particular, no capitalismo - encolheu, ficou mais curto, reduzindo-se a uma sucessão de momentos indistintos sob o véu da novidade (como no fluxo incessante de produção de novas mercadorias), o resultado dessa contração é um embotamento drástico da percepção de ritmos diferenciados de transição, tanto do ponto de vista sensorial como no que diz respeito à experiência espiritual e intelectual. (Gagnebin, 2014: 38).

Tendo em vista esse cenário, nossa hipótese é de que o cinema do eu, mais especificamente, o documentário na primeira pessoa - dado o nível de elaboração do eu/cineasta, a complexidade da produção, e a linguagem já consolidada em gêneros - é capaz de nos fornecer mais elementos para perspectivar ambas as tendências: da espetacularização e da experimentação de si. Nossa proposta não é pensar o cenário propriamente mas, norteado por ele, compreender os modos como o documentário brasileiro na primeira pessoa constrói o eu pela imagem e, ao mesmo tempo, pensa essa construção. Julgamos que, através de uma análise cinematográfica mais nuançada, é possível entender melhor tanto movimentos que referendam os modos de espetacularização quanto aqueles que se abrem à experimentação por meio do entendimento da experiência de si como uma experiência cinematográfica que, a partir de métodos próprios, é constituída na imagem técnica. No limite, trata-se de dar a ver como cinema, com seus recursos próprios de construção de narrativas na primeira pessoa possibilita pensar com os filmes, e para além deles, a experiência que vai do autorretrato à autobiografia.

No domínio da escrita cinematográfica de si, muito dos documentários autobiográficos se utilizam de uma narrativa tradicional e cronológica na tentativa de criar uma identidade coesa: a ilusão da igualdade entre ser, viver e parecer. Em vários deles, o eu se inscreve de forma inflacionada e ganha uma centralidade egóica. A tentativa é de se conceder à experiência e à memória, que é fragmentada, porosa e afetiva, uma coerência que cola cineasta, personagem, vida, e imagem. De modo que a imagem surge como algo da ordem da transparência que só faria refletir o que o sujeito de fato é. Quanto mais envernizado, claro, e próximo às representações simbólicas que institui o documentário como gênero - quer dizer, as associações imediatas entre o filme em primeira pessoa e o que se espera dele - mais distante da experiência de si enquanto elaboração e da memória enquanto processo lacunar instituído pela obra. Nesse sentido, a obra não é concebida como forma que pensa, ela 
mesma capaz de colocar o sujeito em obra ${ }^{1}$, mas como um modo de retratar a si mesmo num ato simbólico de formas cristalizadas e facilmente identificáveis para o espectador.

Em perspectiva oposta, há filmes que mesmo sem deixarem de ser documentais - ou seja de usar estratégias própria do domínio do documentário, do ponto de vista da autobiografia - se encaminham em direção a formas ensaísticas ${ }^{2}$ nas quais o estar na imagem através de um aparato cinematográfico constitui ele mesmo uma experiência de si que já se coloca de saída no limiar entre o ser e o aparecer. Ao contrário de superar essa tensão, como numa superação dialética, o sujeito a experimenta como constituinte da condição de cineasta e personagem de si.

Na esteira de Benjamin, o limiar ao contrário do limite que cerca e delimita é uma figura da ambiguidade, da oscilação, da tensão, e da contradição. Estar no limiar é estar na soleira da porta que pode se abrir como pode se fechar, é estar prestes a tornar-se, ou seja, é um estado da passagem, um estar entre.

$\mathrm{Na}$ arquitetura, o limiar deve preencher justamente a função de transição, isto é, permitir ao andarilho ou ao morador que transite, sem maior dificuldade de um lugar determinado a outro lugar distinto, às vezes oposto. Seja ele simples rampa, soleira da porta, vestíbulo, corredor..., o limiar não faz só separar dois territórios (como uma fronteira), mas permite a transição, de duração variável, entre esses dois territórios. Ele pertence à ordem do espaço, mas também, essencialmente, à do tempo. (Gangnebin, 2014: 36)

A experiência do limiar seria então a experiência de transição que identificamos no cinema em que o eu nunca se constitui totalmente numa identidade fixa mas, para usar as figuras caras a Benjamin, entra no fluxo, no fugidio, na indeterminação que o autor detecta nos ritos de passagem, na morada do sonho, em sua infância em Berlim, nas formas da memória proustiana. ${ }^{3}$

1. Lembramos aqui o belo ensaio de Suely Rolnik em que ela discute as obras da dupla de artistas Maurício Dias \& Walter Riedweg, como dispositivos que "colocam o mundo em obra" (Rolnik, 2003).

2. Entendemos o ensaio aqui tal como Silvina Rodrigues Lopez: "Admite-se assim uma certa flexibilidade da escrita ensaística, que integra a fragmentação, a dissonância, e até mesmo a aceitação da incerteza do conhecimento" (Lopes, 2012: 121).

3. "Ritos de passagem - assim se denominam no folclore as cerimônias ligadas à morte, ao nascimento, ao casamento, à puberdade etc. Na vida moderna, estas transições tornaram-se cada vez mais irreconhecíveis e difíceis de vivenciar. Tornamo-nos muito pobres em experiências limiares. O adormecer talvez seja a única delas que nos restou. (E, com isso, também o despertar.) E, finalmente, tal qual as variações da figura do sono, oscilam também em torno de limiares os altos e baixos da conversação e as mudanças sexuais do amor. "Como agrada ao homem”, diz Aragon, “manter-se na soleira da imaginação!" (Paysan de Paris, Paris, 1926, p. 74). Não é apenas dos limiares destas portas fantásticas, mas dos limiares em geral que os amantes, os amigos, adoram sugar forças. As prostitutas, porém, amam os limiares das portas do sonho. - O limiar [Schwelle] deve ser rigorosamente diferenciado da fronteira [Grenze]. O limiar é uma zona. Mudança, transição, fluxo estão contidos na palavra schwellen (inchar, entumescer), e a etimologia não deve negligenciar estes significados. Por outro lado, é necessário determinar 


\section{Da experiência do eu à autobiografia não-autorizada}

Buscando conceder uma nomenclatura que fosse capaz de encarnar essa noção do gesto autobiográfico no cinema como uma experiência limiar, que se institui na ambiguidade própria do ser e do aparecer, do eu e do outro, que fica como que na soleira entre o documentário e a ficção, o personagem e o cineasta, propomos o termo autobiografia não-autorizada. ${ }^{4}$ A motivação dessa nomenclatura diz respeito à noção de biografia autorizada que se refere ao fato do sujeito que terá sua vida narrada, autorizar e, nessa medida, "controlar" aquilo que irá ser contado sobre si e como será contado. Para a autobiografia essa noção é em si um paradoxo. Como pensar em não autorização uma vez que o sujeito que escreve ou filma o faz sobre si mesmo? Contudo, é justamente tal contradição que nos interessa, pois o significante cifra que também na autobiografia o sujeito tende a construir uma narrativa controlada por padrões de julgamento externos que o auxiliem a simular uma imagem de si coerente e "fiel", no sentido de criar, via ilusão cinematográfica o nivelamento entre vida e obra. Por outro lado, e ao mesmo tempo, ao contrário da biografia não autorizada, o paradoxo da "autobiografia não-autorizada" remete à dificuldade do sujeito - justamente por ser enunciador e enunciado, diretor e personagem do próprio filme - ter controle ou plena consciência do eu que está se construindo, e à possibilidade da obra constituir-se como processo de produção de um si. Dessa maneira, o autorizar-se não se restringe ao âmbito legal - como o biografado que autoriza a escrita de sua biografia uma vez que se imagina dono dela e capaz de dominá-la - mas a um fazer estético e político na medida em que o próprio biografado desaparece enquanto eu referencial ${ }^{5}$ para se conformar como um outro na narrativa cinematográfica. Para Paul De Man, a autobiografia é como uma prosopopeia que faz falar o morto. Nesse processo, a morte é a passagem do sujeito em si - que de trás da câmera assevera o contrato de verdade da obra -, para a imagem que, enquanto desfiguração, só pode alcançá-lo como um traço. Seguindo a pista de De Man, o eu da obra autobiográfica é sempre um intervalo, um vazio deformado, que se instala entre o sujeito que filma e a máscara que ele mesmo constrói ao se inscrever na imagem.

o contexto tectônico e cerimonial imediato que deu à palavra o seu significado. Morada do sonho". (Benjamin, 2007: 535).

4. Ao forjarmos esse conceito percebemos a necessidade de apresentá-lo entre aspas uma vez que a ideia primeira de uma autobiografia não autorizada seria uma aporia, uma vez que aquele que se autobiografa, que faz um relato em primeira pessoa, de si próprio e de sua vida, logicamente não poderia não autorizá-la. Em segundo lugar, optamos por usar o não-autorizada ligado por o hífen remetendo a noção de que tais palavras são inseparáveis (são como uma só) para que o conceito produza sentido.

5. A noção de referencialidade aqui refere-se a existência concreta do sujeito, seja como o autor que escreve - tal qual pensando por Philippe Lejeune (2008) - seja como o sujeito cineasta que filma sua "realidade" portanto uma referencialidade documental. 
(...) o retrato autobiográfico é, para De Man, a sede de um movimento aleatório: o movimento pelo qual o informe sofre uma desfiguração. Pois no instante em que a narração acontece (o 'momento autobiográfico autorreflexivo') aparecem dois sujeitos: um ocupa o lugar do informe, outro o lugar da mascara que desfigura... um $e u$ se apresenta a outro eu, ambos intercambiáveis, ambos substituíveis precisamente por sua heterogeneidade, porque são dois e não um, porque não coexistem nem no tempo nem no espaço. Outorgase um rosto cuja identidade se ignora." (Catelli, 2007: 227 - tradução nossa).

É como se essa desfiguração, a passagem pela morte, que a autorização da biografia tentaria impedir - através de uma narrativa cronológica, na qual as memórias são selecionadas de forma a limpar a história do sujeito de ambiguidades e fracassos, e construir uma identidade coesa - fosse o princípio para a experiência limiar do cinema do eu. No cinema da "autobiografia nãoautorizada", a incerteza e o fracasso ${ }^{6}$ são condições de possibilidade da própria escrita de si, uma vez que a impossibilidade de um eu completo e fixo está na concepção mesma do ato de filmar e montar, e que as lembranças não surgem inteiras perfazendo uma intriga, mas aos pedaços perfazendo um tecido esgarçado, um devir-memória. "Diferente do dever de memória - que para preservá-la a pensa como inteira - o devir memória sabe que ela já é ausência, esquecimento, por isso aposta no presente, no processo de rememoração como um ato de sempre tornar-se." (Veiga, 2015: 95).

\section{Das passagens metodológicas ao recorte analítico nas obras}

Para aproximar-se do cinema como uma autobiografia não-autorizada e entendê-lo como uma experiência limiar, propomos uma análise fílmica que passe pelos aspectos fundamentais em jogo numa escrita de si: o efeito de eu, a rememoração e a experiência com e na obra. $\mathrm{O}$ efeito de eu se refere ao modo como o cineasta se coloca em cena e se relaciona com o seu mundo familiar e íntimo, tanto em termos da mise-en-scène, quando tomado como personagem, quanto na tensão campo e antecampo ${ }^{7}$ quando tomado como diretor, que por

6. “O ensaio é então apresentado com uma construção retórica que, pelo uso de estratégias persuasivas, é particularmente apta para o exercício de um pensamento que se ensaia, um pensamento por tentativas, que não teme o fracasso da totalidade, embora cada fragmento e o todo se organizem pelas relações de vizinhança, que podem ser lógicas, retóricas, ou poéticas". (Lopes, 2012: 128).

7. "Espécie de fora-de-campo mais radical situado atrás da câmera (Aumont, 2004:41), o antecampo funciona de maneira diferente no filme de ficção e no documentário. No primeiro caso, ele constitui um espaço de natureza totalmente diferente, heterogênea em relação ao espaço da cena (da representação); no segundo, será um lugar - marginal, mas constituinte - de permeabilidade entre o real e a representação. Quando aqueles que habitam o antecampo (o diretor, a equipe de filmagem) adentram a cena, o efeito é duplo: de um lado, estes sujeitos antes, fora de campo - ficcionalizam-se um pouco, compõem, de um modo ou de outro (mas de dentro), a representação. Por outro lado, a representação é fendida, passa a abrigar, processualmente, uma relação de mútua implicação e alteração entre quem filma e quem é filmado, entre 
sua vez pode questionar a referencialidade documental num gesto ensaístico. A rememoração se refere ao modo como a memória se institui na obra. Seja através de arquivos, reencenações ou do recurso ao off, interessa saber se ela se inventa no processo de filmagem e montagem, ou se é performada como um resgate do passado no presente. Resta saber se a memória se mantem em sua natureza faltosa e lacunar ou se é preenchida de forma a plasmar o passado no presente. Por fim, o modo como o filme diz de seu processo remete à escritura fílmica e ao caráter de experiência de si que a obra pode mais ou menos ensejar. Nessa medida, esses aspectos nos servem como eixos de análise para pensar a possibilidade de, contrariando a espetacularização de si, o cinema fazer emergir uma experiência limiar, instituída na tensão entre ser e aparência ou na dimensão sempre alter do eu, como ressalta De Man.

Nos últimos anos, é fácil notar produções brasileiras de documentários na primeira pessoa, nos quais o eu do cineasta se coloca, porém sem afirmar-se como ponto de partida, ou objetivo e matéria primeira do filme. Esses filmes nascem, ao contrário, do desejo do cineasta pela história de um outro: um parente próximo. Nesse caso, o processo de lidar com uma história familiar, doméstica, que abriga a vida do próprio cineasta, irá fomentar uma escrita de si. Além da importância que esses documentários vêm ganhando não só no cinema nacional, a escolha desse recorte se justifica ainda pela pertinência metodológica em se falar de uma autobiografia não-autorizada quando se trata de um projeto no qual a escrita em primeira pessoa se faz mediada pela escrita sobre uma segunda pessoa. É ainda curioso enfatizar que no corpus que iremos abordar, os filmes também nascem de uma biografia do outro não autorizada, no sentido em que o personagem biografado, por algum motivo, não autorizou a feitura de um filme sobre si mesmo. Percebe-se, nesse caso, a princípio, uma dupla não-autorização: a do biografado que não pode dar permissão ou negar sua biografia e a do cineasta que ao produzir tal relato sobre um ente próximo acaba por inscrever-se ali indiretamente. Há um jogo com a noção de não autorizado que no primeiro caso diz respeito ao desconhecimento ou à negação do biografado sobre sua biografia e, no segundo, diz respeito ao fato do cineasta estar mais ou menos consciente de que ao construir um filme sobre um familiar está ao mesmo tempo construindo um filme sobre si. Ou seja, ao produzir uma escrita indireta de si, emulada pelo relato de uma vida muito próxima a sua (um parente, o pai, um amigo), o cineasta pode ter mais

mundo vivido (extra-diegético) e mundo fílmico (diegético). O antecampo é assim um recurso estilístico e, simultaneamente, um espaço ético (advém daí, a nosso ver, sua relevância, o que não faz com que essa seja a priori uma exigência ou mesmo um traço valorativo)". (Brasil, 2013: 2). 
ou menos controle de sua inscrição na obra e tem a possibilidade de junto com outro colocar-se em obra.

Contudo, a questão é um pouco mais complexa. Ainda que nesse recorte o modo de inscrição do eu do cineasta na obra seja indireto, há níveis, e até um gradiente para a "autobiografia não-autorizada", que pode inclusive se dissolver por completo caso o gesto ensaístico dê lugar a um documentário mais convencional, ou a experimentação de si dê lugar à espetacularização do eu. Dito de outra forma, ainda que o cineasta faça um documentário sobre um ente estimado em primeira pessoa, não necessariamente estaremos no terreno mesmo da autobiografia não-autorizada, uma vez que, para tal, a experiência da escrita cinematográfica de si deve ser limiar, no que essa abriga de "um lugar ou tempo intermediário" que pode portanto "ter uma extensão variável, mesmo indefinida" (Gagnebin, 2014: 37).

Dentro do recorte e dos eixos analíticos expostos, propomos pensar quatro documentários brasileiros recentes: Diário de uma busca (2010), de Flávia Castro; Elena (2011), de Petra Costa; Mataram meu irmão (2013), de Cristiano Burlan; e Os dias com ele (2012), de Maria Clara Escobar. Se nos três primeiros longas, os cineastas lidam, cada um a seu modo, com a morte de um parente próximo (o pai de Flávia, a irmã de Petra, e o irmão de Cristiano), realizando um trabalho de elaboração pela rememoração, de forma que o processo de filmagem seja uma experiência no presente sobre outra passada, em Os dias com ele, Maria Clara Escobar vai em busca do pai vivo, Carlos Henrique Escobar. É no encontro que o pai desconstrói sistematicamente o filme da filha, ao negar a entrega de sua própria história e, portanto, barrar um possível eu da cineasta que fica sempre por se inscrever. Não é correto dizer que Os dias com ele não passe pela memória, ao contrário, a memória funciona como chave analítica na medida em que o rememorar se faz num presente compartilhado entre filha e pai, cineasta e sujeito filmado. Nesse caso, o cinema será então $\mathrm{o}$ acontecimento presente que impele a figuração de um passado misterioso e turvo de modo disforme e lacunar.

\section{Da memória ao ato, do ato aos arquivos}

Nos três filmes, a experiência cinematográfica constitui-se no embate com o passado, seja a do pai, do irmão ou da irmã mortos, seja a do pai vivo de quem a história esteve sempre interdita. Se há uma pulsão fílmica ela está no desejo de rememorar o distante colocando o passado em obra, ou de reconstituir o passado, performando a memória. Se há uma busca pelo que já foi, ela vai acontecer no presente da experiência com o cinema, que se converte numa busca por si mesmo, uma elaboração mais ou menos precária de si. Em 
Diário de uma busca, Flávia Castro anuncia narrativamente que o filme é uma investigação da circunstância real e obscura da morte do pai, que acaba por se transformar numa busca por uma memória histórica (dos tempos da ditadura e dos exílios na América Latina) e por uma memória da infância da cineasta. Já em Elena e Mataram meu irmão, a busca é, de início, menos por uma situação a se esclarecer, do que por uma memória a se reconstruir, enquanto em $O s$ dias com ele a busca é, de saída, movida tanto por um desejo de memória histórica (o homem que foi preso e torturado no período da ditadura no Brasil), como por um desejo de aproximação com o pai distante (a memória de família).

Flávia, em Diário de uma busca, investiga a morte não esclarecida do pai, Celso Afonso Gay de Castro - um militante de esquerda que foi exilado durante a ditadura, que morou no Chile, na Argentina, na França e na Venezuela, antes de voltar ao Brasil após a anistia. Em 1984, em Porto Alegre, Celso morreu ao invadir o apartamento de um cidadão alemão que teria sido um oficial nazista. Em sua busca por esclarecer os fatos e compreender o que aconteceu, Flávia vai reconstruindo a história de vida do pai e, junto com ela, a sua própria. Ambas as histórias, em seus acontecimentos menores, foram enevoadas pela violência da morte de Celso, e pelos acontecimentos políticos na América Latina em seu período ditatorial. Na tentativa de alinhavar tempos e figurar memórias, o processo fílmico se desdobra em camadas: a manipulação de arquivos; os atos de busca (a volta aos lugares onde esteve durante o exílio); as entrevistas com parentes e amigos da família; e o relato por meio da própria voz off das memórias de criança e adolescente da cineasta.

Entre os filmes aqui convocados, Diário de uma busca é o que mais utiliza dos atos de busca, artifício de rememoração no presente do filme, percorrendo as cidades onde a família se exilou e abrindo-se ao que esses retornos podem guardar como imprevisto, como impulso menos para a recuperação de uma memória do que pela invenção da mesma no ato de retraçar os fios do passado. Como diria Benjamin, “...o importante para um autor que rememora não é o que ele viveu, mas o tecido de sua rememoração, o trabalho de Penélope da reminiscência. Ou seria preferível falar do trabalho de Penélope do esquecimento?" (1994: 37). Se Penélope destece a noite todo tecido que teceu ao longo do dia, na espera por Ulysses, é porque sabe da necessidade do esquecimento para viver a lembrança do outro que ama. É desse esquecimento, dessa lacuna, que parte Flávia. Ao mesmo tempo em que tenta preenchê-lo, os percursos e situações do processo de busca revelam uma tensão constante entre o que é possível e o que não é possível lembrar-se. Cada encontro na casa, na escola, na embaixada, onde Flávia esteve ou viveu, dispara afetos e reminiscências, e enseja uma configuração em que a cineasta é colocada num 
entre-lugar, entre passado e presente, entre memória e invenção. Ao ser interrogada pelo então morador de sua outrora casa no Chile sobre se o homem que impulsiona o filme seria alguém importante, Flávia responde: ele era meu pai. O filme enseja situações nas quais ao ser convocada a sair do antecampo e se colocar na cena para dizer de seu pai, de sua vida e de sua infância, ela surge num limiar entre o que foi e o que poderia ter sido, entre realidade e ficção. Porém, ao mesmo tempo em que essa experiência limiar escapa, a cineasta tenta perpetrar um sentido coeso para a narrativa de forma a permitir uma ordem biográfica.

Em Elena, Petra Costa vai rememorar a morte da irmã, através de uma reconstituição que se define fortemente pela mise-en-scène da própria cineasta. Elena suicidou em 1990, com 20 anos, na cidade de Nova York, onde fora morar com a mãe e Petra ainda criança, com intuito de dar continuidade a seus estudos de teatro. Vinte e três anos depois, a cineasta volta a Nova York, para encenar uma busca pela irmã. Já de início estamos numa sequência que se repete ao longo do filme, no qual Petra anda pelas ruas da cidade simulando cenograficamente sua procura por Elena, com quem fala em voz off, ao modo de uma narrativa epistolar. Assim como em Diário de uma busca, o filme conjuga arquivos, depoimentos, revisitações, encenações e um off constante na primeira pessoa. Porém, o ato de retorno de Petra a Nova York torna a cidade e seus espaços mais um cenário para a mise-en-scène já pré-determinada da diretora, do que uma forma de conexão com a irmã, ou de passagem para outros mundos, que seria possível em função da pregnância de sentidos e afetos do lugar, ou dos possíveis encontros que, na feitura do filme, ensejariam uma reinvenção da memória. É como se a biografia da irmã não pudesse se valer dos fiapos que constituem o processo mnemônico em sua materialidade imprecisa, em sua textura esgarçada, mas exigisse uma cola a produzir um relato coeso da identidade do biografado. Há, sem dúvida, momentos de puro afeto nos arquivos em vídeos caseiros, a exemplo daqueles nos quais Petra, ainda bebê, dorme ao lado de Elena que a espia e a conforta, ou quando Elena dança vigorosa e displicentemente, como se naquele momento a câmera (com certeza empunhada por algum parente) amenizasse o peso das instituições artísticas americanas que ela almejava fazer parte. Porém, o excesso de imagens de arquivo familiar a preencher a história totalmente apaga a dimensão processual que o filme poderia ter para dar lugar a um filme-sintoma. Ou seja, o filme revela o sintoma de uma sociedade na qual o viver, o (se) filmar, e o dar(-se) a ver, se estilizam perfazendo uma só aparência e sinalizando de forma bastante emblemática o que Debord afirmou em suas teses sobre o espetáculo. 
As imagens fluem desligadas de cada aspecto da vida e fundem-se num curso comum, de forma que a unidade da vida não pode mais ser restabelecida. A realidade considerada parcialmente reflete em sua própria unidade geral um pseudo mundo à parte, objeto de pura contemplação. (Debord, 1972: 13-14).

Essa dimensão contemplativa da qual nos fala Debord, ao contrário do que o filme faz parecer, não aproxima Elena do ensaio, pois o ensaio instala atritos onde uma experiência limiar da diferença, da separação e da passagem é sentida. Tão pouco aproxima o filme do documentário que se faz no encontro com outro, tal qual pensado por Comolli, ${ }^{8}$ e observado nos outros filmes abordados que se instituem na fricção com o real que os interpela.

Menos ambicioso do que um projeto de investigação das circunstâncias oficiais da morte do irmão, e menos pessoal e intimista do que uma rememoração marcada pela auto-mise-en-scène para a câmera, em Mataram meu irmão, o retorno à experiência passada - o assassinato do irmão do cineasta, Rafael Burlan, em 2001, no Capão Redondo, periferia de São Paulo - se faz pelas bordas e não por dentro. O filme é, predominantemente, entrevistas com parentes e amigos da família e a voz off do cineasta é uma manifestação pontual. Vimos que em Diário de uma busca o uso dos arquivos pontua a passagem do tempo em sua heterogeneidade, no qual a foto em várias texturas e dispositivos é mais presente, barrando inclusive o fluxo cinematográfico. Já em Elena, os arquivos ainda que múltiplos preenchem as lacunas do tempo em sua profusão e extensão, sendo o vídeo predominante. Já em Mataram meu irmão o uso do arquivo é muito restrito. Cristiano volta ao Capão Redondo e visita parentes e amigos do irmão. Sempre do antecampo, ele fala pouco durante as entrevistas, deixando que essa biografia não-autorizada do irmão se faça através do testemunho dos outros. Os espaços são mostrados a distância, sem o preenchimento de uma voz que narra, tornando-se assim menos o cenário de uma história individual, do que uma ambiência marcada pelas mazelas sociais que atingem muitos dos jovens nas favelas do Brasil.

No quarto filme elencado, Os dias com ele, algo da cineasta surge também do antecampo, de forma indireta e opaca, através da lida com outro, da interação com o pai vivo. Maria Clara Escobar praticamente não coloca sua voz off e as poucas imagens de arquivo que temos são de famílias quaisquer. Não há nenhuma tentativa de cronologizar a história do pai, Carlos Henrique Escobar. O filme é todo feito como uma longa entrevista dentro da casa, autoexílio, de

8. "Para nós, a distinção entre ficção e documentário deve se orientar por uma práxis que fundamenta nosso desejo de ver e fazer cinema documentário, o que implica, necessariamente, um encontro com o outro e com o desejo que sua imagem-realidade seja apreendida em seus próprios termos, não numa dimensão conceitual e abstrata, e sim material, gestual, corporal; em sua hecceidade, sem que isso implique uma visão ingênua que crê "dar voz ao outro". (Caixeta e Guimarães, 2008: 36). 
Escobar em Portugal, onde Maria Clara passa dias testando formas de saber, acessar, reconstituir, a experiência de tortura que o pai sofrera em sua prisão durante a ditadura, e buscando pistas de suas relações familiares, principalmente com ela própria. Ela lança questionamentos dos quais o pai sempre se esquiva, sempre desvia, ou devolve para a filha na forma de outros questionamentos sobre a feitura do filme, o planejamento e o método, criando assim um campo de disputa pela direção do filme e abrindo uma zona tensa e oscilante entre passado e presente. Maria Clara se desenha ao mesmo tempo frágil e insistentemente na voz que vem do antecampo, nas tentativas de elaborar seu projeto de filme para o pai e de precisar suas questões. Dessa forma, transforma o que seria uma autobiografia numa dobra menos sobre si mesma do que sobre o fazer cinematográfico que está em jogo naquele presente duradouro da conversa com o pai. O pai que nunca autoriza completamente o relato de si e a filha que se reinventa na necessidade de obter essa autorização. Trata-se, portanto, de um filme que com o pretexto de voltar ao passado das memórias do pai para dizer de sua vida, acaba por se tornar um embate presente apanhado na mise-en-scène de ambos, de um para o outro, onde os personagens se constroem para a obra e na obra. Nessa medida, como advogava Ana Cristina César, em seu pensamento sobre o cinema biográfico "canônico" que mumificava seus personagens ao lhe conferirem uma identidade nobre e coesa, $O s$ dias com ele se coloca na contramão:

Num movimento de contradição com o sério fluir do documentário, o filme poderá mencionar a própria intervenção, desnaturalizando-se pela via crítica do auto-refletir-se. Fazer documentário e ao mesmo tempo indagar-se (embora discretamente, sem radicalidade) sobre o que é fazer documentário: indagação basicamente antidocumental. (César, 1980: 49).

Além dos atos de busca e das entrevistas, Flávia e Petra, como já dito, utilizam largamente o material de arquivo doméstico fazendo com que os personagens mortos vivam durante quase todo o filme, de modo que a narrativa seja um arco cronológico que vai da vida feliz, ativa, dos personagens, aos sinais de tristeza ou desespero que levam morte. Em Mataram meu irmão, a vida de Rafael só aparece pelas lembranças dos entrevistados. Só há uma foto de família amarelada, cheia de borrões, de três garotos saindo do mar que supomos ser Cristiano, Rafael e o outro irmão. Por seu isolamento no filme, e sua falta de nitidez, a foto assinala a impossibilidade de reviver o irmão pela imagem, a impossibilidade de dissociar vida e morte. Os outros arquivos nos quais vemos a imagem de Rafael são as fotos de identificação que ilustram o arquivo policial. Ao restringir enormemente o recurso aos arquivos como forma de figurar as memórias, e também por esses cobrirem não uma voz off confessional e memorialística, mas uma conversa ao telefone (no caso da foto dos 
irmãos) e uma trilha sonora (no caso dos arquivos policiais), Cristiano acaba inscrevendo fortemente esses arquivos no presente e deflagrando com tal gesto a impossibilidade de volta ao passado, a impossibilidade de ter o passado nas mãos. O material fotográfico só pode ser um traço do que foi, um gesto de apagamento, do esquecimento por vir que o filme de alguma maneira ainda impede (gesto metaforizado por Hollis Frampton em Nostalgia, de 1971). A foto é menos a sobrevivência da imagem pelo arquivo como salvaguarda da memória, do que um rastro a se apagar, a deixar de ser, mas que por outro lado e, paradoxalmente, sobreviverá no filme. Mesmo incrédulo da ilusão cinematográfica de reviver o irmão morto, mesmo certo do seu impoder, a foto solitária faz com que o cinema de Cristiano se curve à rememoração, se curve ao poder da imagem em movimento como duração.

Ao contrário de Diário e Elena, Mataram meu irmão está bem próximo de Os dias com ele cujas únicas fotos que vemos como sendo de família, as do pai da cineasta a brincar com ela, são na verdade arquivos domésticos quaisquer. Há nesse caso uma negação do arquivo como lugar de sobrevivência ou, até mesmo de vivência do outro, como se, desacreditando da memória plasmada na imagem, só fosse possível reencontrá-la nos interstícios, nas intermitências, que sobram entre as imagens, seja na mise-en-scène seja na montagem.

\section{Da primeira pessoa às muitas por vir}

Em seu ensaio "Nada tudo qualquer coisa ou a arte das imagens como poder de transformação" dedicado ao pensamento de Godard sobre a imagem, Maria-José Mondzain diz: "No império do espetáculo total é tempo de destronar a pretensão totalitária das imagens e restituir o seu poder ao terceiro em devir, isto é, o povo dos espectadores" (Mondzain, 2011: 105). Ao contrário do espetáculo que tudo dá a ver, que apaga o esquecimento e a indeterminação em prol da exibição, Mondzain alerta para o "nada" das imagens que deve conduzir o gesto dos criadores ao devir qualquer coisa destinado a um povo por vir. Aqui, esse terceiro, o povo espectador, rompe a dicotomia do biografado e do autobiografado, bem como o primado da primeira pessoa. Se para Mondzain, ao reviver a velha formula de Godard de que o cinema é mistério, assim como a morte, então a memória assim como o "eu" nunca se realizará por inteiro, pois não há um passado, uma identidade, ou uma essência a ser revelada. Apostando na distância entre o que foi (a história do pai e da família no passado) e o que é (na interação presente no processo fílmico), Maria Clara sinaliza para um poder ser do cinema como invenção, ou para o que pode vir a ser pelo olhar dos espectadores. 
Como já dito, ao falarem de si através de um outro, os quatro diretores aqui elencados constroem uma autobiografia indireta. Porém, não deixam de ser construções narrativas cuja centralidade varia na forma como a presença de cada um se faz sentir e no modo como misturam as instâncias de narrador, cineasta e personagem. É na medida em que essa centralidade se expande construindo intercessões e passagens que uma experiência de limiar dá condições para que a "autobiografia não-autorizada" se constitua e a primeira pessoa venha acolher a terceira e toda uma comunidade de espectadores. ${ }^{9}$

Elena é o filme em que o eu que narra está mais exposto e centralizado. Não apenas em função das inúmeras imagens de arquivo nas quais a cineasta aparece, da firme direção das interpretações, das cenas em que ela passeia só pelas ruas de Nova York mas, principalmente, pela condução da narrativa amarrada cronologicamente e pelo modo como, após o episódio da morte da irmã, a diretora assume o protagonismo das cenas e se filma inúmeras vezes, virando a câmara para si mesma: o rosto bem de perto, em close, pensativa, dançando no teatro e na rua. Na verdade, o filme faz um jogo de duplicidade entre ela e a irmã, como se ambas se confundissem (por isso Petra parece interpretar a si mesmo e Elena). A semelhança física e da voz favorece essa duplicidade que, em alguns momentos, inclui a mãe (que aparece jovem no filme), perfazendo menos uma triplicidade do que uma identificação. Ao contrário de marcar a separação entre elas e ressaltar a dimensão alter do eu que narra, essa duplicidade acaba por colar as histórias, ultrapassando as diferenças, e impedindo a experiência limiar. O terceiro não pode vir, a não ser como o mesmo, acoplado em uma identidade dada, conduzido pelo mesmo mundo, o mundo de Elena-Petra. Quando um afeto irrompe na tela e a possibilidade do entre-imagens é perscrutada, num instante depois já é novamente capturada pelo fluxo do espetáculo do qual nos fala Debord. Trata-se mais precisamente de um espetáculo do eu, da primeira pessoa, que faz o filme recair no sintoma de uma sociedade onde, na esteira do pensamento de Paula Sibilia (2008), a imagem não é ação que engaja o sujeito num pathos, mas produto que se comercializa. Uma sociedade na qual o sintoma é tirar um selfie e postar no Facebook ou mandar um snapchat, pois a relação que se estabelece entre o mundo e a imagem é uma relação instantânea (aquela do tempo do consumo), que não concede ou oferece o tempo necessário para que a vida em sua dura-

9. “... no ensaio aquilo a que habitualmente se chama uma 'voz pessoal' e que é uma voz em que a descentração se torna visível sem nunca se chegar à perda de um efeito de centro, sem nunca se chegar ao ponto em que as relações de vizinhança das palavras se estabelecem de tal modo que seu 'ordenador' desaparece, deixa de ser ele a saber. É esta característica que define o estatuto mediado do ensaio, e o situa, como "subjetividade de um não-sujeito", precisamente como impulso de desfixação das relações sujeito-objeto, força anti-identitáia ou combate à opinião". (Lopes, 2012: 123). 
ção encontre ela mesma, module ela mesma, seu devir imagem, para além do imediato.

Em Diário de uma busca, apesar de Flávia demonstrar um certo controle na condução das entrevistas e da narrativa cronológica há, como vimos, uma descentralização da figura do eu confessional que narra, atua e dirige. Além dos momentos específicos em que o descontrole dos encontros é inevitável, a descentralização ocorre ainda na forma ambígua como a cineasta procura compartilhar o filme com Joca, seu irmão que, ao seu lado, questiona muitas vezes o processo num ato metalinguístico incorporado ao próprio filme. Se no ato de se aproximar do pai, a cineasta também dele se afasta é, principalmente, porque o mundo adulto da política, do exílio, da ditadura, parece sempre se oferecer como um obstáculo para o que é coisa de infância. Aqui a experiência limiar se oferece na tensão que ao unir dá a ver a dimensão sempre intransponível desses dois mundos, o de um e o do outro, o da criança e o do adulto, o do exílio político e o da liberdade infantil.

Em Mataram meu irmão, Cristiano é bem mais opaco. Porém, ainda que o filme não se atenha ao registro confessional, logo no início Cristiano anuncia seu projeto pessoal quando, sobre uma tela preta, durante uma conversa ao telefone com a funcionária do Cemitério, declara seu desejo de visitar o irmão morto que lá está enterrado. Em seguida, sobre cenas noturnas do trânsito da cidade, ele confessa que jamais se esquecerá do dia em que soube do assassinato do irmão a tiros no Capão Redondo e das palavras da mãe que até hoje lhe atormentam. O cineasta relembra a última visão de Rafael fumando crack, o abalo e a culpa que sentiu. Ao citar Herman Hesse, demonstra o desejo de sinceridade e também a impossibilidade que define a escrita de si: "Não é agradável minha história, não é suave e harmoniosa como as inventadas. Sabe a insensatez e a confusão, a loucura e o sonho, como a vida de todos os homens que já não querem mais mentir a si mesmo".

É interessante notar ainda como essa dimensão pessoal, do eu que é personagem, pode se conservar na medida em que o filme desliza completamente para o documentário, naquilo que define a inscrição verdadeira, o encontro com o outro, a câmera e o tempo presente. Nesse sentido, o antecampo, lugar um tanto quanto escondido do documentarista é um importante descentralizador do eu, pois o diretor só passa para o campo na medida em que a cena, e o dispositivo, o convocam. Se o antecampo parece apagado em Elena, uma vez que Petra não interage com outras pessoas (a não ser com a mãe que encena seus depoimentos sob orientações performáticas da diretora), ele é a base da construção autobiográfica de Mataram meu irmão e de Os dias com ele. É dali que, hesitantemente, de forma mais ou menos oblíqua, os perso- 
nagens/cineastas se inscrevem. Ainda que Cristiano não se manifeste, o antecampo é como que tensionado para dentro da cena, fazendo coincidir a história que é contada com a história de quem escreve. No último encontro com a sobrinha, o antecampo é invadido pela adolescente que abraça o tio-cineasta a chorar do outro lado, e pelo sobrinho mais novo, que, até então acabrunhado nos cantos do quadro, também o abraça longamente, fazendo implodir as instâncias de quem filma e quem é filmado.

Já em Os dias com ele esse movimento do antecampo é acirrado de tal forma que o filme parece construir um dispositivo onde o pai que está no campo, na mira das lentes, ganha uma equivalência em termos de atenção do espectador com o que ocorre atrás da câmera, onde está a filha. Maria Clara arma seu aparato de tal forma que o pai não sabe quando está ou não sendo filmado, portanto se coloca muitas vezes como aquele que escuta, e não aquele que vai encenar para a câmera, nesses momentos a voz que ouvimos forade-campo, vem do antecampo, da filha, que tenta refazer percursos, explicitar estratégias, expor seu projeto para que o filme aconteça numa dinâmica que parece sempre a espera do fracasso, a espera de não se realizar. Esse dispositivo preenche o filme de uma não expectativa, portanto de uma limiaridade constante, que une e polariza pai e filha, reinventado na forma fílmica a separação emocional e familiar entre eles. Se o filme é uma experiência de limiar, é porque a passagem para o outro não se dá totalmente, apenas se esboça, se projeta como um possível. Ainda que hesitante, e muitas vezes frágil, opacizado por se encarnar na voz, o lugar da cineasta está ali, de certa forma, resguardado, há um eu - figura do discurso e da história - a se formular atras da câmera, porém um eu-ponte-e-porta, um eu que ao mesmo tempo separa e faz o elo para que haja um entre o pai e a filha, uma memória comum, inventada no ato cinematográfico. Nessa medida, o eu não tem nada de uma interiorização, de uma identidade, que deseja se exteriorizar para o outro, mas se lança como um intermezzo, como a possibilidade que entre a imagem de Carlos Henrique e Maria Clara exista algo. Algo de incompleto, de surdo e mudo, de gaguejante, mas persistente e tenso. Da primeira pessoa para a segunda (eu, filha, e você, pai, na minha frente) existe a experiência do limiar que não é uma fronteira demarcada, mas uma possibilidade de separação e passagem (daí a metáfora da eu-ponte-e-porta), ${ }^{10}$ é nela que sobrevivem todas as outras múltiplas imagens que a terceira pessoa, o povo por vir dos espectadores, virá a construir. O filme nega o 'eu' como instância enunciativa única, convocando a todo momento a

10. "George Simmel analisou a questão do limiar num artigo de 1909, intitulado "Ponte e porta". Segundo ele, trata-se de dois exemplos de formas concretas, pelas quais o espírito humano chegou a objetivar o fluxo incessante e indomável da vida. A ponte e a porta são a projeção no espaço da nossa capacidade de unir o que está separado e separar o que está unido" (Collomb, 2010: 116). 
partilha. O autobiográfico, a escrita de si, de uma primeira pessoa, é de saída não-autorizada, porque é a única possibilidade de que haja filme, é o próprio dispositivo.

Adentrar a escritura de cada filme em relação à biografia do outro, nos permite pensar através de níveis, escalonamentos - que vão da centralidade, e exposição da primeira pessoa, ao descentramento e intermitência do eu -, os modos como a dimensão não-autorizada da autobiografia incide e se produz no cinema. Contudo, podemos dizer que em Os dias com ele encontramos mais fortemente o espírito da concepção que tentamos sustentar ao longo do texto de que para que haja uma experiência de si na e com a imagem é preciso que essa se dê na liminaridade, movimento, rito de passagem, pelo qual a subjetividade se reinventa e se abre para mundos possíveis, alternativos à espetacularização do eu.

\section{Referências bibliográficas}

Benjamin, W. (1994). A imagem de Proust. In Magia, técnica, arte e política. Obras escolhidas. São Paulo: Brasiliense.

Benjamin, W. (2007). Passagens. Belo Horizonte: Editora UFMG; São Paulo: Imprensa Oficial do Estado de São Paulo.

Brasil, A. (2013). Formas do antecampo: notas sobre a performatividade no documentário brasileiro contemporâneo. Anais da XXII Compós. Salvador-BA.

Caixeta, R. \& Guimarães, C. (2008). Pela distinção entre ficção e documentário, provisoriamente. In J.-L. Comolli, Ver e Poder - a inocência perdida: cinema, televisão, ficção, documentário. Belo Horizonte: Editora UFMG.

Catelli, N. (2007). En la era de la intimidad - seguido de: El espacio autobiográfico. Rosario: Beatriz Viterbo Editora.

Collomb, M. (2010). Limiares, aprendizagem e promessa em Infância em Berlim por volta de 1900. In G. Otte, S. Sedlmayer, et al. (org) Limiares e passagens em Walter Benjamin. Belo Horizonte: Ed. UFMG.

César, A.C.C. (1980). Literatura não é documento. Rio de Janeiro: FUNARTE.

Debord, G. (1972). A sociedade do espetáculo. Lisboa: Edições Afrodite.

Gagnebin, J.M. (2014). Limiar, aura e rememoração: ensaio sobre Walter Benjamin. São Paulo: Editora 34.

Lejeune, P. (2008). O pacto autobiográfico. BH: Ed. UFMG. 
Lopes, S.R. (2012). Literatura, Defesa do Atrito. Belo Horizonte: Chão de Feira.

Mondzain. M.J. (2011). Nada tudo qualquer coisa ou a arte das imagens como poder de transformação. In R. Silva \& L. Nazaré (org). A república por vir. Arte, Política e Pensamento para o século XXI. Lisboa: Fundação Calouste Gulbenkian.

Sibília, P. (2008). O show do eu: a intimidade como espetáculo. Rio de Janeiro: Nova Frenteira.

Rolnik, S. (2003). Alteridade a céu aberto. O laboratório poético-político de Maurício Dias \& Walter Riedweg. Catálogo de exposição dedicada aos artistas no Museu de Arte Contemporânea de Barcelona.

Veiga, R. (2015). Já visto jamais visto: um filme de filmes ou o devir memória. Crítica Cultural - Critic, , jan./jun., 10(1): 87-96. Palhoça, SC. 